AperTO - Archivio Istituzionale Open Access dell'Università di Torino

\title{
Adaptation of fungi, including yeasts, to cold environments
}

\section{This is the author's manuscript}

Original Citation:

Availability:

This version is available http://hdl.handle.net/2318/133164

since 2016-08-10T11:33:09Z

Published version:

DOI:10.1080/11263504.2012.753135

Terms of use:

Open Access

Anyone can freely access the full text of works made available as "Open Access". Works made available under a Creative Commons license can be used according to the terms and conditions of said license. Use of all other works requires consent of the right holder (author or publisher) if not exempted from copyright protection by the applicable law. 
This is the author's final version of the contribution published as:

O. Maggi; S. Tosi; M. Angelova; E. Lagostina; A.A. Fabbri; L. Pecoraro; E. Altobelli; A.M. Picco; E. Savino; E. Branda; B. Turchetti; M. Zotti; A.

Vizzini; P. Buzzini. Adaptation of fungi, including yeasts, to cold environments. PLANT BIOSYSTEMS. 147(1) pp: 247-258.

DOI: $10.1080 / 11263504.2012 .753135$

The publisher's version is available at:

http://www.tandfonline.com/doi/abs/10.1080/11263504.2012.753135

When citing, please refer to the published version.

Link to this full text:

http://hdl.handle.net/2318/133164 


\section{Adaptation of fungi, including yeasts, to cold environments}

DOI: $10.1080 / 11263504.2012 .753135$

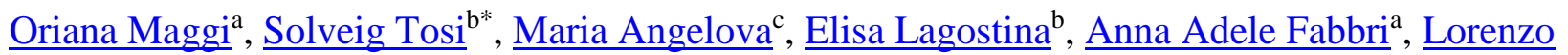

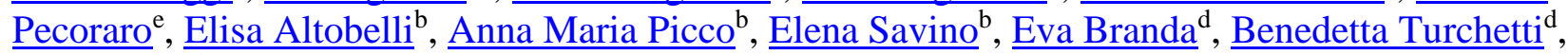
Mirca Zotti $^{\mathrm{f}}$, Alfredo Vizzini $^{\mathrm{g}}$ \& Pietro Buzzini $^{\mathrm{d}}$

\section{Author affiliations}

- $\quad$ a Dipartimento di Biologia Ambientale , Sapienza Università di Roma , Italy

- $\quad{ }^{\mathrm{b}}$ Dipartimento di Scienze della Terra e dell'Ambiente, Laboratorio di Micologia , Università di Pavia , Italy

- $\quad{ }^{\mathrm{c}}$ The Stephan Angeloff Institute of Microbiology, Bulgarian Academy of Sciences , Bulgaria

- ${ }^{\mathrm{d}}$ Dipartimento di Biologia Applicata and Industrial Yeasts Collection DBVPG , Università di Perugia , Italy

- $\quad$ e Institute of Agricultural and Environmental Sciences, Estonian University of Life Sciences , Estonia

- $\quad{ }^{\mathrm{f}}$ DISTAV (Dipartimento di Scienze della Terra, dell'Ambiente e della Vita), Laboratorio di Micologia , Università degli Studi di Genova , Italy

- $\quad$ g Dipartimento di Scienze della Vita e Biologia dei Sistemi , Università di Torino , Italy

\section{Abstract}

A wide range of cold environments exist, with an equally broad variety of fungi and yeasts that have adapted to such environments. These adaptations, which affect membranes, enzymes and other cellular components, such as radical scavenging molecules, display a great potential for exploitation in biotechnology. Alterations have been detected in membrane lipids, with an increase in fatty acid unsaturated bonds that enhance their fluidity. We report new data on the different phospholipid composition in membrane lipids in the same fungal species from both Antarctic and temperate regions. The decrease in temperature causes intracellular oxidative stress by inducing the generation of reactive oxygen species. We report the results of the first analysis of the non-enzymatic antioxidant response and phenolic compound production by an Antarctic strain of Geomyces pannorum. A survey on yeasts from the cryosphere is reported with a focus on their adaptation to a cold environment. Some studies have shown that the number of macrofungi in glacier forefronts rises as deglaciation increases. The survival success of many plants in such areas may be attributed to their mycorrhizal associations. We highlighted the macrofungal biodiversity of some Italian alpine habitats, in which we Inocybe microfastigiata, Laccaria montana and Lactarius salicisherbaceae were recorded for the first time in Lombardy (Italy). 


\section{Keywords}

- Fungi and yeast,

- cold adaptation,

- membrane lipids,

- radical scavenging activity,

- phenolic production,

- macrofungal biodiversity

\section{Introduction}

The term psychrophilic was coined by Morita (1975) for microorganisms whose cardinal minimum, optimum and maximum growth temperatures are, respectively, at or below 0,15 and $20^{\circ} \mathrm{C}$, whereas microorganisms with a higher growth optimum and maximum were called psychrotrophic (Eddy 1960). Currently the terms psychrophile and psychrotolerant are preferred, because it is the former, not the latter, that has truly adapted to grow exclusively at low temperatures (Russell 2008). Psychrophiles are a family of extremophiles, i.e. organisms that survive under physicochemical conditions far removed from those that represent a suitable environment for human beings (Gerday 2002; Selbmann et al. 2012, this issue).

Among the coldest environments, the cryosphere represents one of the largest unexplored and extreme biosphere systems, and it includes the ecosystems characterized by the presence of ice in extensive masses (Benn \& Evans 1998), such as cold deserts, glacial habitats and permafrost (Margesin \& Miteva 2011). Because of its extremely harsh climatic conditions, Antarctica has been for many years the geographic region chosen by a worldwide range of microbiologists for exploring diversity of cold-adapted microorganisms (Onofri et al. 2007). However, a number of more recent studies highlighted that psychrophilic microorganism populations can successfully colonize nonAntarctic cryosphere as well (Buzzini et al. 2012). Arctic areas and glaciers of high-mountain complexes, such as Himalaya, Alps and Andes are glacial areas which also represent rich sources of psychrophiles and psychrotolerants (Thomas-Hall et al. 2010; Turchetti et al. 2011).

The viability of microorganisms in cold environments has been the focus of interest for many years, and glacial ice is an excellent preservation matrix for microbial life (Newsham 2012); the longevity of microorganisms entrapped in ice (including those from alpine environments) has consequently become a subject of study (Catranis \& Starmer 1991; Abyzov 1993; Persiani et al. 2011; among others).

Physiological mechanisms conferring cold tolerance on fungi are complex and not yet fully understood; they include increases in unsaturated membrane lipids (Russell 2008), the production of RNA chaperones to suppress the formation of undesired secondary RNA structures (Kwak et al. 2011), the synthesis of antifreeze (García-Arribas et al. 2007) and cold shock proteins (Horn et al. 2007), as well as cold-active enzymes (Gatti-Lafranconi et al. 2010). A combination of these mechanisms is necessary for the psychrotroph or psychrophile to function (Robinson 2001). The aim of this study was to highlight some of the adaptations displayed by fungi and yeasts to cold environments, and particularly to focus on the large ecosystem complex of cryosphere, the Antarctic continent and alpine glacier forefront.

\section{Increase in unsaturated membrane lipids in fungi from the Antarctic}

The Antarctic region is dominated by microorganisms with a high level of adaptation. The Antarctic mycobiota in particular has been investigated, among others, by Italian researchers from a qualitative, ecophysiological, molecular and phylogenetic point of view (Onofri et al. 2007). Most of the filamentous fungi are cosmopolitan species, some of which are psychrophilic whereas many 
more are psychrotolerant; responses of Antarctic fungi to different stresses appear to be similar to those found in temperate regions (Ruisi et al. 2007; Onofri et al. 2011).

Cold-adapted microorganisms have evolved mechanisms to deal with the thermodynamic constraints of low temperatures, whereas membrane composition can determine the ability of fungi to grow outside specific temperature ranges. Psychrophiles increase the degree of disorder within macromolecules to maintain fluidity or flexibility and, consequently, to maintain their function at low temperatures (Russell 1990; Robinson 2001; D'Amico et al. 2006). Cold-adapted fungi and yeasts respond by modulating the fluidity of their membrane (Weinstain et al. 2000; Russell 2009; Turk et al. 2011), which is mainly achieved by altering the fatty acid composition through an increase in the proportion of unsaturated fatty acids.

In order to investigate how phospholipid composition has changed in the cell membranes in fungi, the composition of seven species from the Antarctic [Aspergillus versicolor (Vuill.) Tirab, Cadophora fastigiata (Lagerb. \& Melin) Conant, Cladosporium cladosporioides (Fresen.) G.A. de Vries, Geomyces pannorum (Link) Sigler \& J.W. Carmich, Mortierella alpina Peyronel, Mortierella antarctica Linnem., Scolecobasidium salinum (G.K. Sutherl.) M.B. Ellis] and of five of the same species from temperate habitats [A. versicolor, C. cladosporioides, G. pannorum, $M$. alpina, S. salinum] was analysed after the species had been incubated at two different temperatures (8 and $25^{\circ} \mathrm{C}$ ). The Antarctic samples from which the fungi were isolated were collected in different sites of the "Terra Nova Bay” during Italian Antarctic Expeditions.

Different culture conditions were designed to support both mesophilic and xerotolerant growth by using the following culture media: malt extract agar, Czapek agar, Czapek yeast extract agar, potato dextrose agar and 25\% glycerol nitrate agar (G25N, a $\mathrm{a}_{\mathrm{w}}$ 0.955) (Pitt \& Hocking 1985).

The isolated fungal strains were then inoculated on liquid media (potato dextrose broth and Czapek broth) by suspending mycelia in distilled $\mathrm{H}_{2} \mathrm{O}+$ Triton $\times 100(0.1 \%$, w/v). The fatty acid composition analyses of the mycelial polar lipid fraction were carried out after 14 days of incubation by means of thin layer chromatography and gas chromatography according to Finotti et al. (1993).

Table I shows the comparison of concentrations in the polar lipid fraction between common fungal species in the Antarctic and those in temperate regions. Each value is the mean of three determinations. The $t$-test was used to assess the significance of differences in concentrations between the strains grown at $25^{\circ} \mathrm{C}$ and those grown at $8^{\circ} \mathrm{C}$. The table shows that the palmitic (16:0), stearic (18:0), oleic (18:1) and linoleic (18:2) acids are present in all the fungal strains analysed, regardless of the habitat of origin. As regards the unsaturated fatty acids, oleic acid quantities were higher $(p<0.05-0.001)$ both in the strains of $C$. cladosporioides and $S$. salinum and in the Antarctic strain of $C$. fastigiata when these strains were grown at $8^{\circ} \mathrm{C}$ than when they were grown at $25^{\circ} \mathrm{C}$. Linoleic acid also increased $(p<0.001)$ in the $A$. versicolor and $G$. pannorum strains, as well as in the $S$. salinum strain from Antarctica when grown at $8^{\circ} \mathrm{C}$. This increase was also observed in the Antarctic strains of Geomyces vinaceus and G. pannorum by Finotti et al. (1993). 
Table 1 Comparison of mean value concentrations of fatty acids, as a percentage of the total fatty acids concentration, in the same fungal species from Antarctic and temperate locations (each value is the mean of three determinations $\pm \mathrm{SE}$; $p$, significance of differences in the concentration at 25 and $8^{\circ} \mathrm{C}$, carried out with $t$ test).

Saturated fatty acids

$\begin{array}{llll} & & \\ & 14: 0 & 16: 0 & 18: 0 \\ \stackrel{\circ}{ }^{\circ} & & \\ C & & \end{array}$

Unsaturated fatty acids

Ot

her

18:2

18:3

20:4 20:5 s

C

Species )

A. 23.9

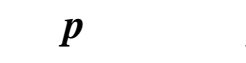

$p$

$\boldsymbol{p} \quad \boldsymbol{p}$

$p \quad p$

p $\quad$ \%

versicol

$\begin{array}{ll}2 & 3.9 \\ 5 & \pm 0\end{array}$

or

$\begin{array}{ccc} \pm 0 . & 05 \pm 0.4 \quad 00 \pm 0.2 .00 \\ 19 & 7 & 1\end{array}$

(Vuill.)

Tirab.

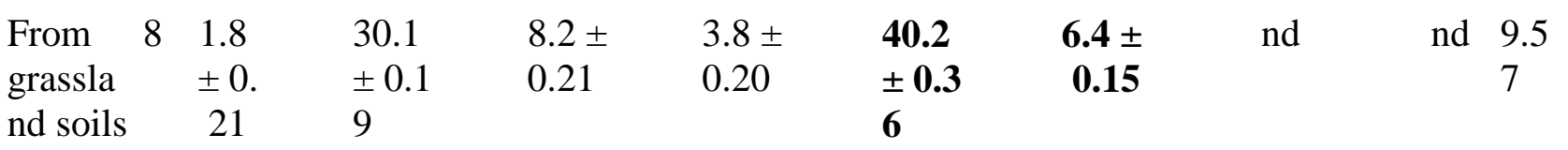

of

Spain

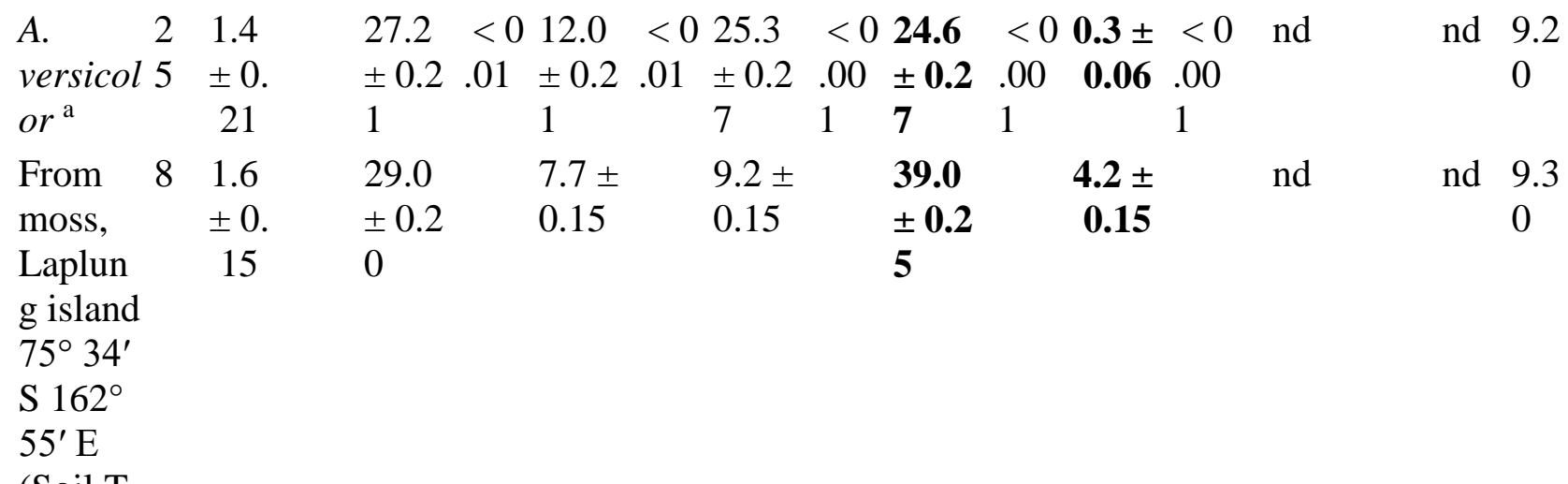

(Soil T

$2^{\circ} \mathrm{C}$ )

Cadoph 2 nd $\quad 24.2<04.5 \pm<09.4 \pm<047.0<0$ 0.9 $\pm<0$ nd $\begin{array}{lllllllllllll}\text { ora } & 5 & \pm 0.1 & .00 & 0.12 & .01 & \mathbf{0 . 1 5} & .05 & \pm 0.0 & .00 & \mathbf{0 . 0 3} & .00\end{array}$

$\begin{array}{lllllll}\text { fastigia } & 7 & 1 & & 1 & 1 & \end{array}$

$t^{a}{ }^{\text {a }}$

(Lagerb

. \&

Melin)

Conant

From 8 nd

$17.8 \quad 3.3 \pm$

10.6

33.6

25.4

nd

nd 9.2

Tigriop

us sp.

$\pm 0.1$

0.15

$\pm 0.2$

$\pm 0.2$

$\pm 0.2$

5

7

1 nd 14 .

03

(Copep

od) 
Saturated fatty acids

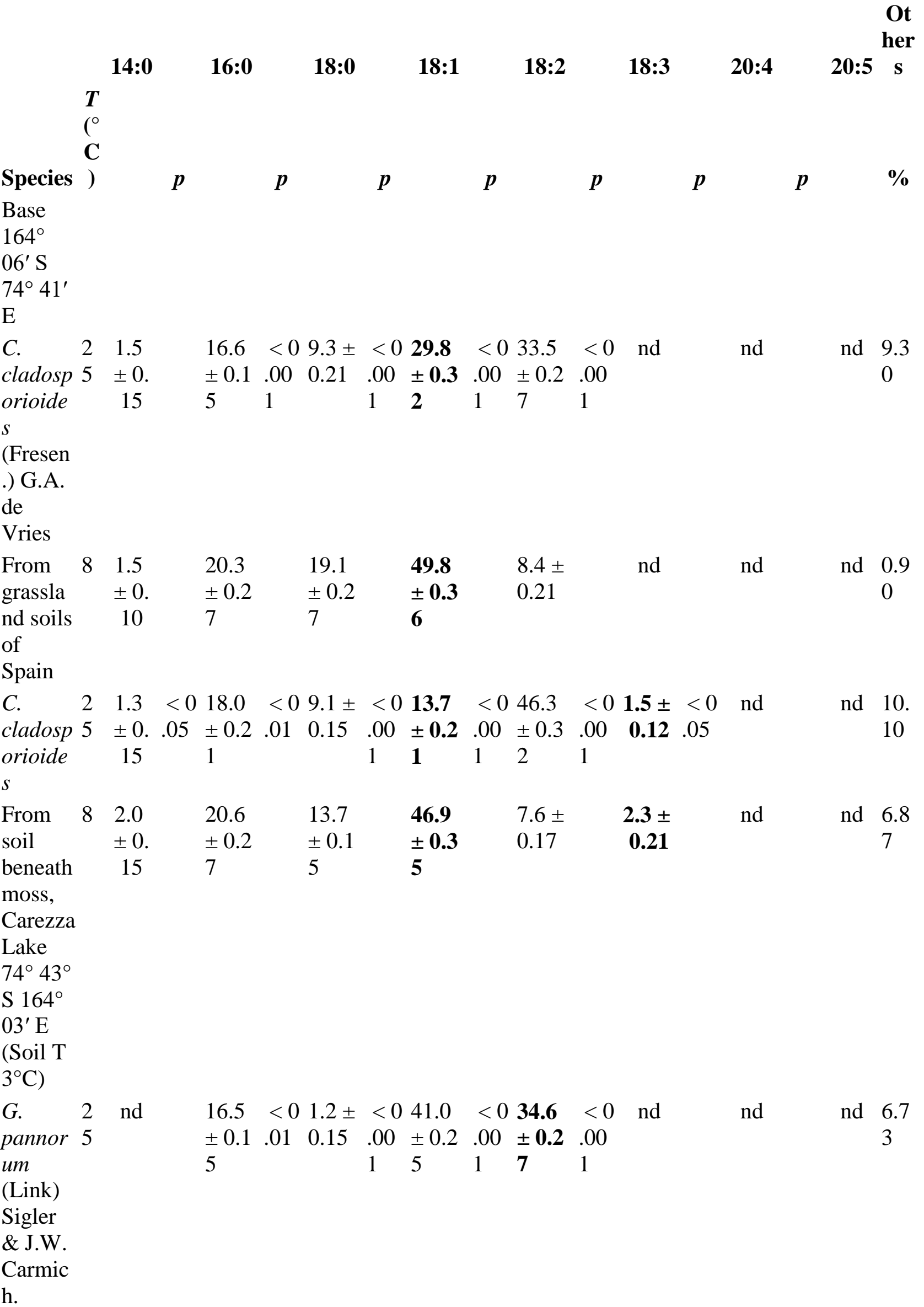


Saturated fatty acids

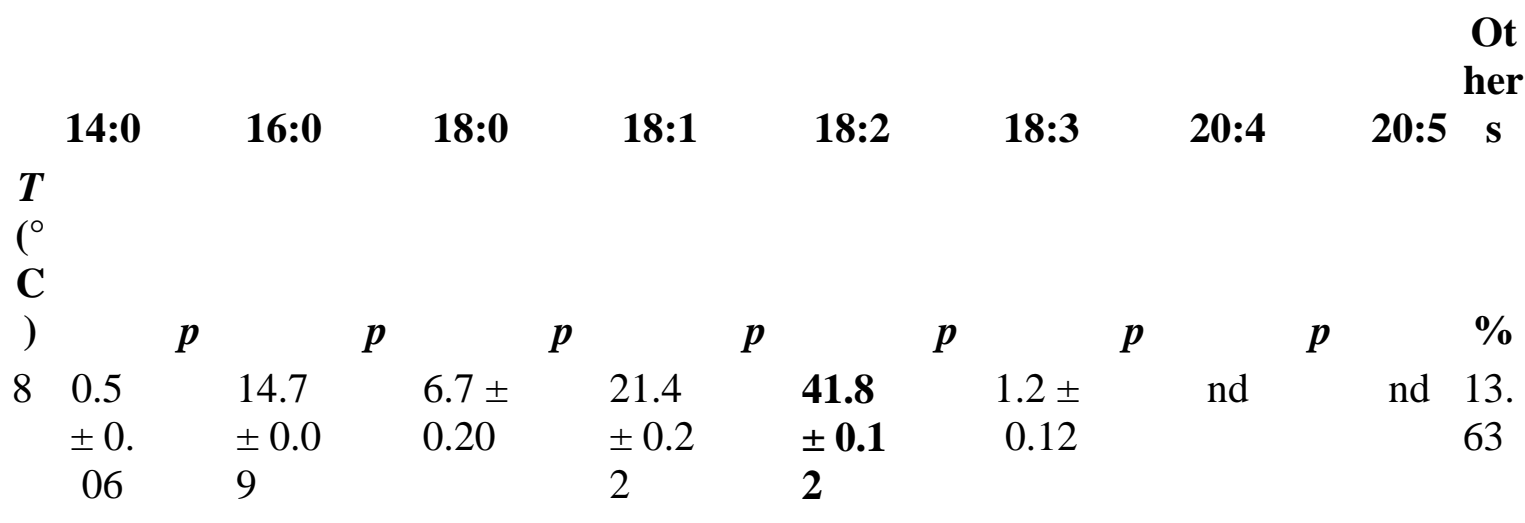

Species )

grassla \pm 0 .

nd soils $\quad 06$

of

Spain $\begin{array}{llllllll} \pm & 0.1 & .00 & 0.12 & .01 & \pm 0.2 & .00 \quad \pm 0.2 & .00\end{array}$

pannor 5

um

From $8 \quad 1.3$

soil, $\quad \pm 0$. $5 \quad 1$

18.3

$4.1 \pm$

$\pm 0.1$

0.15

1

Inexpre

06

5

ssible

Island

$74^{\circ} 56^{\prime}$

S $163^{\circ}$

$45^{\prime} \mathrm{E}$

(Soil T

$2.7^{\circ} \mathrm{C}$ )

M. $\quad 2 \quad 1.0<022.2<08.9 \pm<09.4 \pm<010.0<0$ nd $\begin{array}{llllllllllll}\text { alpina } & 5 & \pm 0 . & 00 & \pm 0.1 & .00 & 0.21 & .00 & 0.15 & .01 & \pm 0.2 & .00\end{array}$

Peyron $\quad \begin{array}{llllll}10 & 1 & 5 & 1 & 1\end{array}$

el

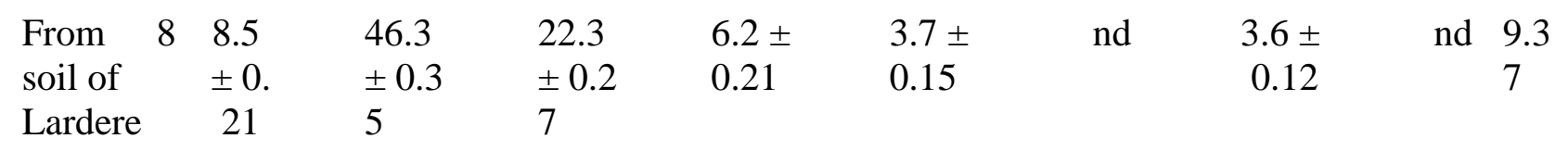

llo

(Tuscan

y)

M. $\quad 2 \quad 1.2<024.0<08.6 \pm<025.8<013.8<00.5 \pm$

$\begin{array}{lllllllllllll}\text { alpina } & 5 & \pm 0 . & 01 & \pm 0.1 & 00 & 0.23 & .01 & \pm 0.4 & .01 & \pm 0.2 & .00 & 0.12\end{array}$

$10 \quad 5 \quad 1$

From $8 \quad 3.2 \quad 37$

soil

beneath

\pm 0 .

37.1

10.8

\begin{abstract}
2
\end{abstract}
21.8

7

$5.3 \pm$

0.17

$\pm 0.1 \quad \pm 0.2$

1
$34.8<0 \quad 0.6 \pm 13$.

$\pm 0.2 \quad 00 \quad 0.1213$

$\begin{array}{ll}7 & 1\end{array}$

$12.5<0$ nd 13 .

$\pm \mathbf{0 . 2} .00 \quad 60$

11

19.8 nd 2.0

$\pm 0.2$

7

moss

Carezza

Lake

$74^{\circ} 43^{\circ}$

$\mathrm{S} 164^{\circ}$

$03^{\prime} \mathrm{E}$ 
Saturated fatty acids

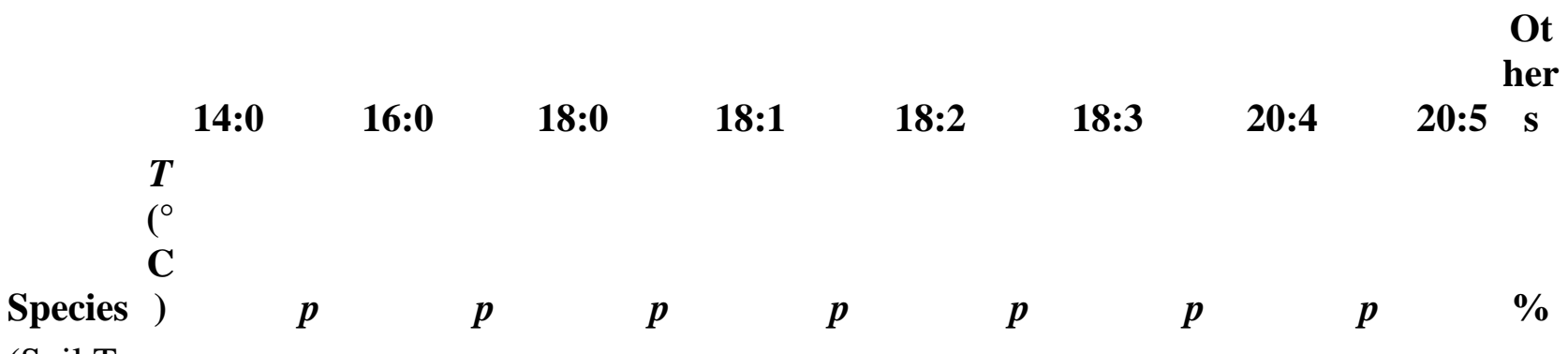

Unsaturated fatty acids

\section{Ot}

her

(Soil T

$\left.3^{\circ} \mathrm{C}\right)$

Mortier $23.8<025.8<05.6 \pm<030.4<018.1<0$ nd $2.7 \pm<0$ nd 13 . $\begin{array}{llllllllllll}\text { ella } & 5 & \pm 0 . & 00 & \pm 0.1 & .00 & 0.12 & .00 & \pm 0.2 & .00 & \pm 0.1 & .00\end{array}$ $\mathbf{0 . 1 5} .00 \quad 73$ $\begin{array}{llllllllll}\text { antarcti } & 15 & 1 & 9 & 1 & 1 & 5 & 1 & 5 & 1\end{array}$ $\mathrm{Ca}^{\text {a }}$

Linnem

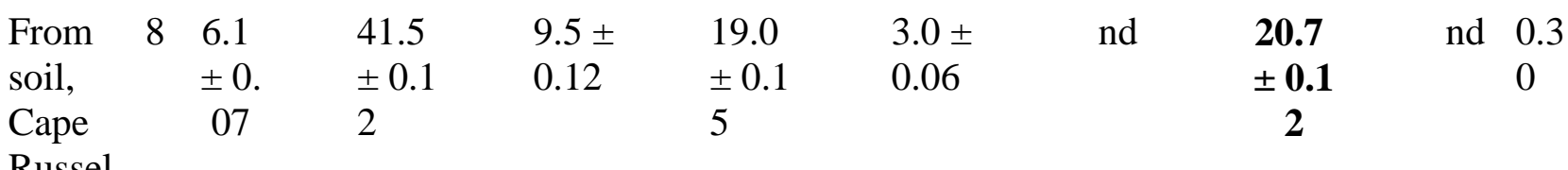

Russel

$75^{\circ} 00^{\prime}$

$\mathrm{S} 163^{\circ}$

$45^{\prime} \mathrm{E}$

(Soil T

$\left.2^{\circ} \mathrm{C}\right)$

S. $\quad 2$ nd $26.8<06.7 \pm \quad \mathbf{4 8 . 0}<04.6 \pm \quad$ nd 4 nd 13 .

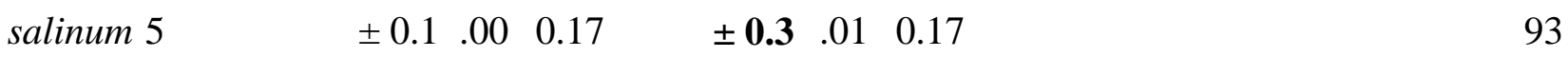

(G.K. $5 \quad 1$

0

Sutherl.

) M.B.

Ellis

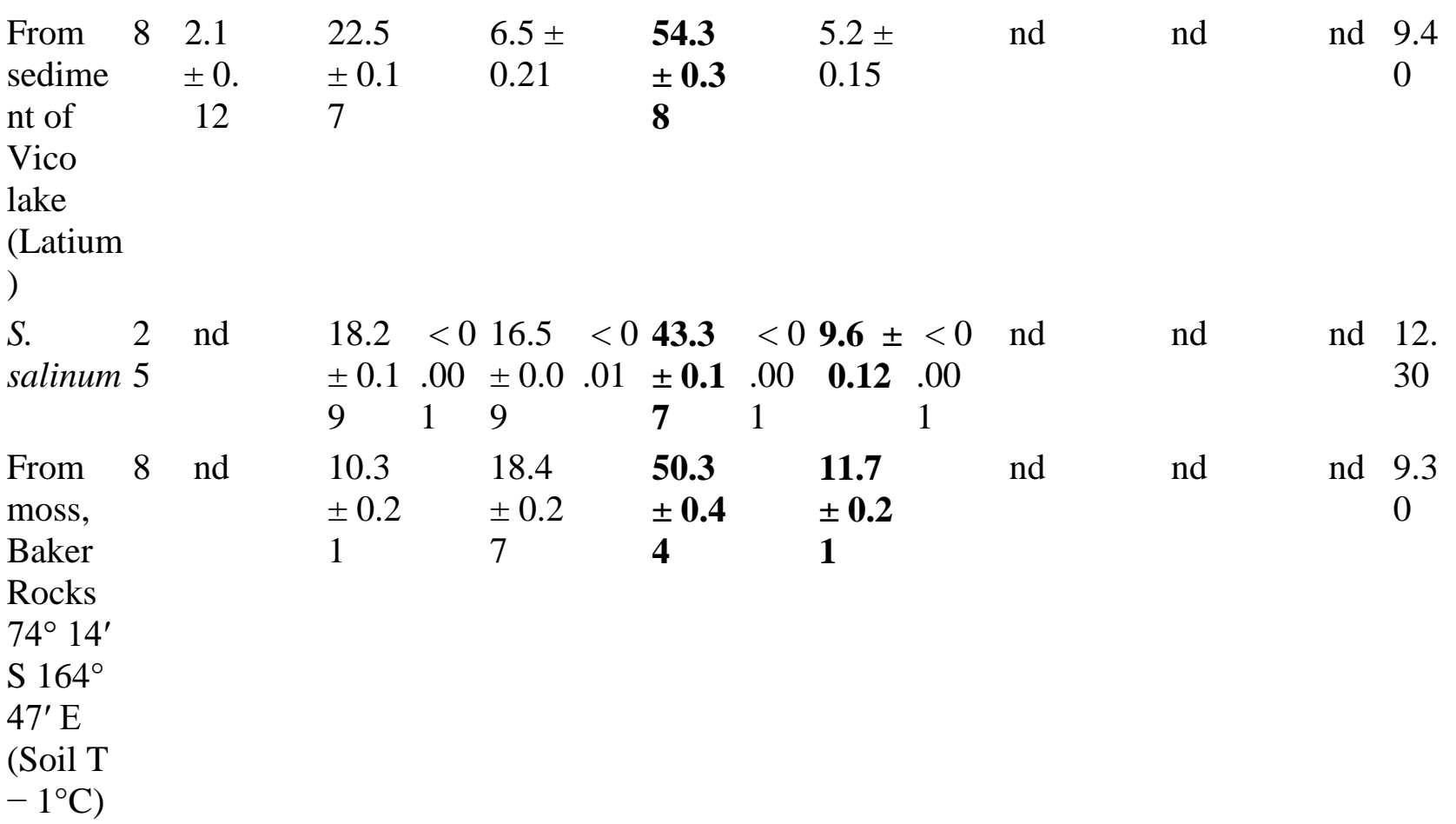


Saturated fatty acids

18:0

18:1

18:2

18:3

Unsaturated fatty acids

$T$
(
C

Species )

$p$

p

$p$

$p$

$p$

$p$

$p$

$\%$

As regards the strains we analysed, the two species of $A$. versicolor and the Antarctic strains of $C$. fastigiata and $C$. cladosporioides displayed a significant amount of linolenic acid (18:3), which was higher $(p<0.05-0.001)$ at $8^{\circ} \mathrm{C}$. The Antarctic strains of $M$. alpina and $M$. antarctica revealed high amounts of arachidonic acid $(20: 4)$, which increased $(p<0.001)$ in strains cultivated at $8^{\circ} \mathrm{C}$.

Jang et al. (2005) reported that the production of polyunsaturated acids depends on the source of carbon and nitrogen in culture media, but also increases as the temperature decreases. In addition, Weete \& Gandhi (1999) claimed that members of the subgenera Mortierella and Micromucor could be identified according to the presence or absence, respectively, of arachidonic acid. Worthy of note is the production of eicosapentaenoic acid (20:5) exclusively by the strain of M. alpina, which originated in a temperate region, when grown at $25^{\circ} \mathrm{C}$. This fatty acid has been attracting a great deal of attention on account of its beneficial effects on human health (Dewey et al. 2007, among others) and for a rapid identification of important pathogen bacterial species (Moss et al. 1980$)$.

Table II shows the significance of differences ( $t$-test) in fatty acid concentrations (expressed as percentages of the overall fatty acid concentration in the polar lipid fraction) in fungal species that are common in both the Antarctic and temperate regions when grown at $8^{\circ} \mathrm{C}$. Each value is the mean of three replicates.

\section{Table 2 Significance of difference (carried out with $t$-test) in the mean value concentrations of fatty acids ( \pm SE), as a percentage of the total fatty acids concentration, in the same fungal species from Antarctic and temperate locations, at $8^{\circ} \mathrm{C}$.}

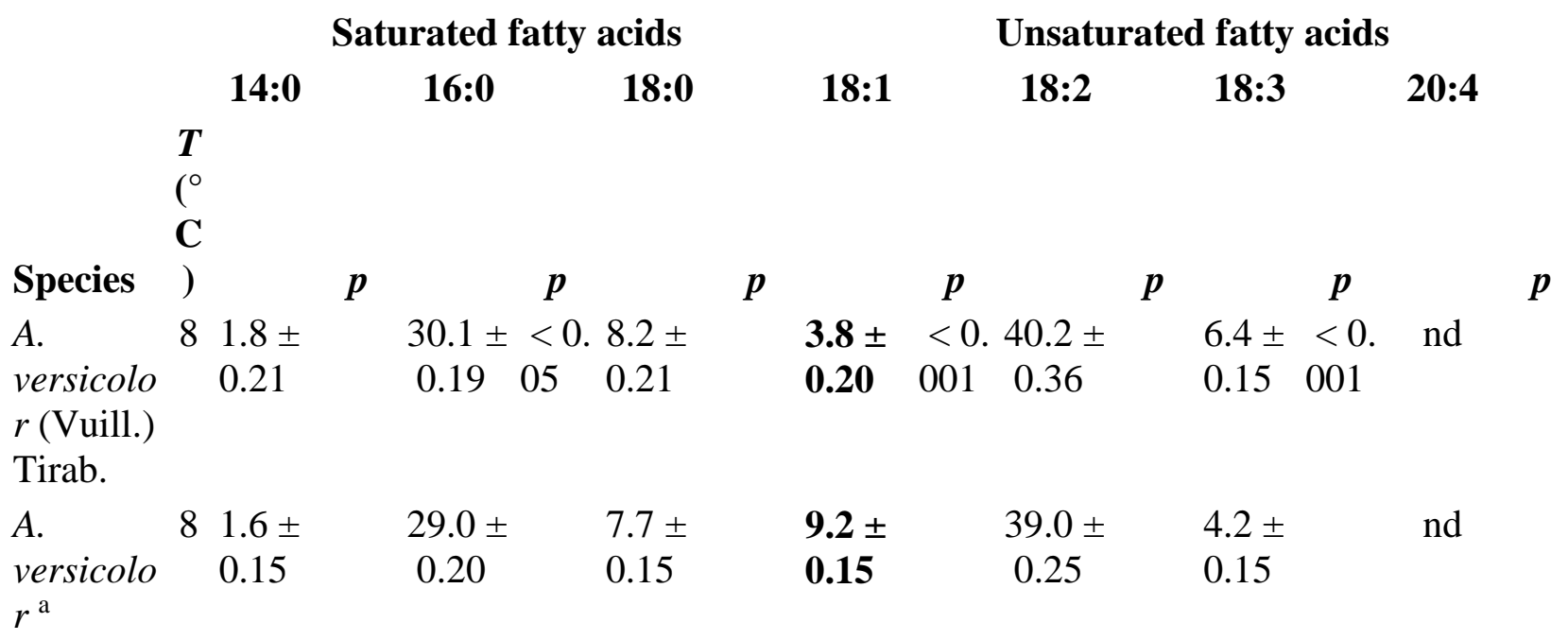




\section{Saturated fatty acids}

$\begin{array}{lllllll}14: 0 & 16: 0 & 18: 0 & 18: 1 & 18: 2 & 18: 3 & \text { 20:4 }\end{array}$

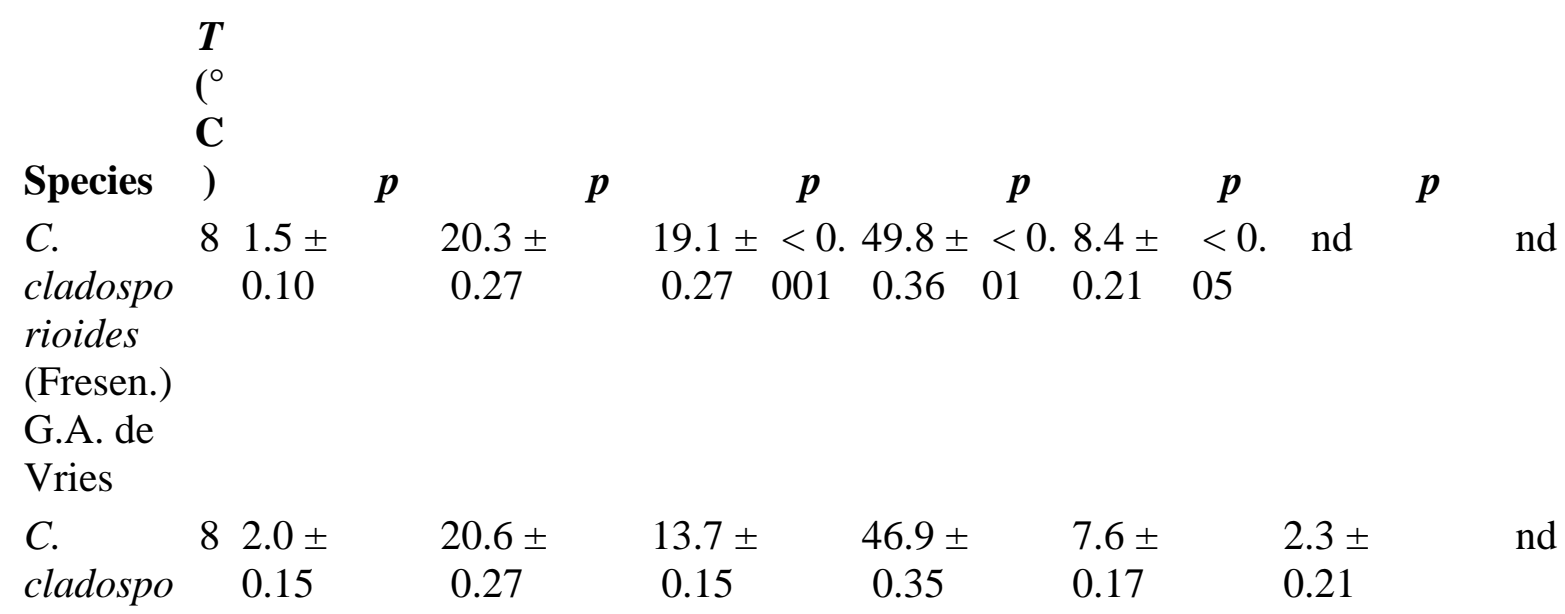

G.

$80.5 \pm<0.14 .7$

$14.7 \pm<0.6 .7$

$6.7 \pm<0.21 .4 \pm<0$.

$41.8 \pm<0.1 .2 \pm<0$. nd

pannoru 0.06001

$\begin{array}{lll}0.09 & 001 & 0.20\end{array}$

$\begin{array}{lll}001 & 0.22 \quad 001\end{array}$

0.12001

0.12001

$m$ (Link)

Sigler \&

J.W.

Carmich.

$\begin{array}{lcccccccr}\text { G. } & 8 & 1.3 \pm & 18.3 \pm & 4.1 \pm & 11.8 \pm & \mathbf{4 7 . 3 \pm} & \mathbf{8 . 0} \pm & \text { nd } \\ \text { pannoru } & 0.06 & 0.15 & 0.15 & 0.15 & \mathbf{0 . 3 2} & \mathbf{0 . 1 5} & \end{array}$

$m^{\text {a }}$

M.

$88.5 \pm<0.46 .3 \pm<0.22 .3 \pm<0.6 .2 \pm<0.3 .7 \pm<0$. nd

alpina

$\begin{array}{llll}0.21 & 001 & 0.35 & 001\end{array}$

0.27001

$\begin{array}{llll}0.21 & 001 & 0.15 & 001\end{array}$

$3.6 \pm<0$.

$\mathbf{0 . 1 2} 001$

Peyronel
M. $\quad 8 \quad 3.2 \pm$
$37.1 \pm \quad 10.8 \pm$
$21.8 \pm$
$5.3 \pm$
nd
$19.8 \pm$
alpina $^{\mathrm{a}}$
0.15
0.21
0.15
0.21
0.17
0.27

S. $\quad 82.1 \pm \quad 22.5 \pm<0.6 .5 \pm<0.54 .3 \pm<0.5 .2 \pm<0$. nd $\quad 0.27$

salinum $\quad 0.12$

$\begin{array}{lll}0.17 & 001 & 0.21\end{array}$

$001 \quad 0.38 \quad 01$

$\mathbf{0 . 1 5} 001$

(G.K.

Sutherl.)

M.B.

Ellis

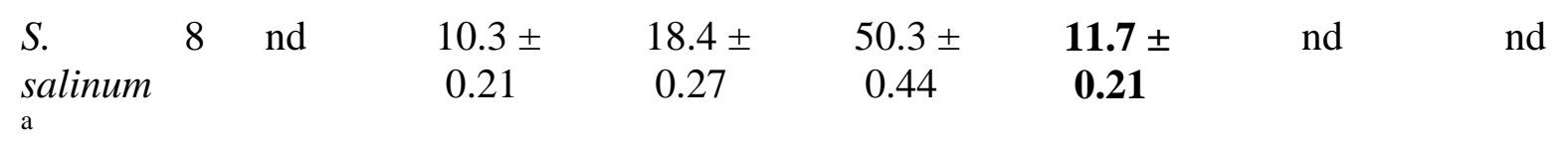

Note: Bold values indicate data on the unsaturated fatty acid concentration that are significantly different.

Worthy of note is the fact that differences for unsaturated fatty acids were almost always significant ( $p=<0.05-0.001$ ). Oleic and linoleic acid levels increased, respectively, in the Antarctic strains of $A$. versicolor and S. salinum, whereas linoleic and linolenic acid levels increased in the Antarctic strain of G. pannorum. The Antarctic strain of M. alpina displayed an increase in oleic, linoleic and arachidonic acid levels. 
These results taken as a whole clearly show that the effect of low temperature is associated with an increase in membrane unsaturated fatty acids in all the species considered. This adaptation process is particularly evident in $80 \%$ of the Antarctic species.

\section{Antioxidant activity in fungi from the Antarctic}

Cold-adapted microorganisms have developed special mechanisms to overcome the lifeendangering influence of low temperature and to survive cold-induced oxidative stress. The decrease in temperature causes intracellular oxidative stress by inducing the generation of reactive oxygen species (ROS) (Fridovich 1998; Gocheva et al. 2009) that can damage cellular components such as DNA, proteins and lipids. To scavenge ROS, aerobic cells have developed a complex defense system consisting of both low-molecular mass scavengers and high-molecular mass antioxidants, in particular antioxidant enzymes, such as superoxide dismutase (SOD) and catalase (CAT) (Angelova et al. 2005; Chattopadhyay et al. 2011; Krumova et al. 2012).

In order to gain further insight into the possible mechanisms underlying fungal survival in extremely cold conditions, cell response of Antarctic fungi to cold stress was investigated by Tosi et al. (2010) and Kostadinova et al. (2012). The results of these investigations showed that fungal cell responses to cold shock are dependent to a greater extent on species than on the degree of cold stress.

Antarctic microorganisms are assumed to possess lower rates of enzymatic and transport processes; this promotes a decrease in ATP demand and a subsequent accumulation of electrons in the respiratory chain, which in turn leads to a sudden increase in the production of the number of ROS (Chattopadhyay 2002). The importance of SOD and CAT for stress protection has been highlighted by Tosi et al. (2010) and Krumova et al. (2012), who demonstrated that Antarctic fungi are good producers of SOD and CAT. However, an Antarctic strain of G. pannorum (Link) Sigler \& Carmichael was one of the less efficient producers of CAT and SOD (Tosi et al. 2010; Krumova et al. 2012). How then can G. pannorum overcome the climatic conditions found in the Antarctic? This paper provides the first report of the non-enzymatic antioxidant response and phenolic compound production displayed by this Antarctic strain.

The fungus was isolated from a soil sample collected in the austral summer of 2006-2007 near the Bulgarian base of St Kliment Ohridski $\left(62^{\circ} 38^{\prime} 29^{\prime \prime} \mathrm{S} 60^{\circ} 21^{\prime} 53^{\prime \prime} \mathrm{W}\right)$ on Livingston Island in the Maritime Antarctic. G. pannorum (strain B) was analysed under optimal growth temperature and after cold and heat shock. Analyses were carried out on lyophilized mycelium from 10-day-old cultures grown at $20^{\circ} \mathrm{C}$ in $250 \mathrm{ml}$ shaking flasks containing liquid Sabouraud culture medium. The results were compared with those recorded for a G. pannorum strain isolated in a Thracian tomb in Bulgaria (strain T), with environmentally controlled conditions in the interior. Data-sets were subjected to a $t$-test for independent samples at a $5 \%$ level of significance.

The diphenylpicrylhydrazyl radical (DPPH) scavenging activity was estimated according to Molyneux (2004), and by following the method reported by Cheung et al. (2003) with some modifications. An amount equal to $2 \mathrm{~g}$ of lyophilized fungus was left shaking overnight in absolute methanol. An aliquot of $1 \mathrm{ml}$ DPPH radical (Sigma) (methanol solution, $0.1 \mathrm{mM}$ ) was added to a test tube with $33 \mu \mathrm{l}$ of the fungus extract in methanol. Pure methanol was used as a blank. The reaction mixture was vortex-mixed and absorbance (Abs) was determined after $1 \mathrm{hr}$ by measurement at $517 \mathrm{~nm}$ with a Jasco 7800 spectrophotometer (Jasco, Easton, MD, USA). Ascorbic acid standards were prepared in different concentrations, whereas DPPH radical scavenging activity was expressed as $\mathrm{mM}$ of ascorbic acid equivalent $\left(\mathrm{mg}^{-1}\right.$ of sample dry weight).

Total phenolics were assayed using the Folin-Ciocalteau reagent (Singleton et al. 1999), following Waterhouse (2001) with some modifications. A mixture was prepared with $1 \mathrm{ml}$ of water, $65 \mu \mathrm{l}$ of the Folin-Ciocalteu reagent (Sigma-Aldrich, St. Louis, MO, USA) and $13 \mu$ of sample. The mixture was shaken and allowed to stand for $8 \mathrm{~min}$, before the addition of $195 \mu \mathrm{l}$ of saturated $\mathrm{Na}_{2} \mathrm{CO}_{3}(20 \%, \mathrm{w} / \mathrm{v})$. After incubation in the dark for $2 \mathrm{~h}$, absorbance was measured at $765 \mathrm{~nm}$ 
versus a blank. The total fungal phenolic concentration was expressed as $\mathrm{mM}$ of gallic acid equivalent ( $\mathrm{mg}^{-1}$ of sample dry weight) with the help of a calibration curve prepared with gallic acid. All samples were analysed in triplicate. Non-enzymatic antioxidant activity and phenol production were measured after cold and heat shock. Following 10 days of growth, cultures were maintained at $4^{\circ} \mathrm{C}$ or $37^{\circ} \mathrm{C}$ for $72 \mathrm{~h}$, and then analysed according to the method cited above.

The DPPH-radical scavenging activity of the G. pannorum strain $B$ is presented in Figure 1 and is compared with that of G. pannorum strain T. Antioxidant production at the optimal temperature for growth $\left(20^{\circ} \mathrm{C}\right)$ is plotted together with the production after cold $\left(4^{\circ} \mathrm{C}\right)$ and heat $\left(37^{\circ} \mathrm{C}\right)$ shock. Production of strain $B$ was significantly different from that of strain $T$ at $20^{\circ} \mathrm{C}$ and after cold shock. When the Antarctic strain was under cold shock, the response was threefold higher than at $20^{\circ} \mathrm{C}$; no difference was recorded after heat shock. Strain $T$ did not exhibit any significant change after cold or heat shock. The strong radical scavenging activity response of the G. pannorum strain $B$ after cold shock was consistent with fungus phenolic production (Figure 2) expressed as gallic acid equivalent. After a $4^{\circ} \mathrm{C}$ cold shock, phenolic production was 2.4 -fold higher than that at $20^{\circ} \mathrm{C}$. A significant difference was also recorded after heat shock, though it was less marked.

Figure 1 DPPH radical scavenging activity of a G. pannorum strain isolated from Maritime Antarctica (B) and from a climatically controlled environment (Thracian tomb) (T). Activity is expressed as $\mathrm{mM}$ of Ascorbic acid equivalent per mg of dry weight at optimal temperature $\left(20^{\circ} \mathrm{C}\right)$ (grey column), after $72 \mathrm{~h}$ shock at $4^{\circ} \mathrm{C}$ (white column) and $37^{\circ} \mathrm{C}$ (black column). Data are the mean of three replicates with standard deviation (bar).

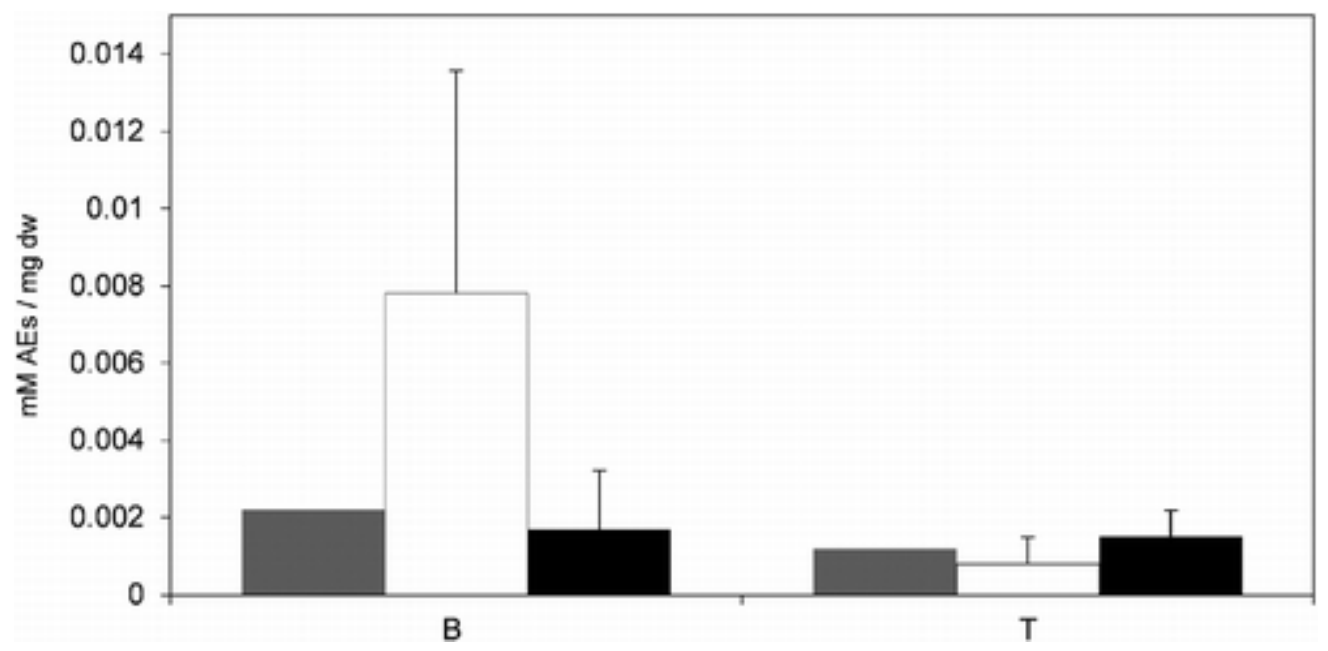


Figure 2 Total phenolic compound production of a G. pannorum strain isolated from Maritime Antarctica (B) and from a climatically controlled environment (Thracian tomb) (T). Activity is expressed as $\mathrm{mM}$ of Gallic acid equivalent per $\mathrm{mg}$ of dry weight at optimal temperature $\left(20^{\circ} \mathrm{C}\right)$ (grey column), after $72 \mathrm{~h}$ shock at $4^{\circ} \mathrm{C}$ (white column) and $37^{\circ} \mathrm{C}$ (black column). Data are the mean of three replicates with standard deviation (bar).

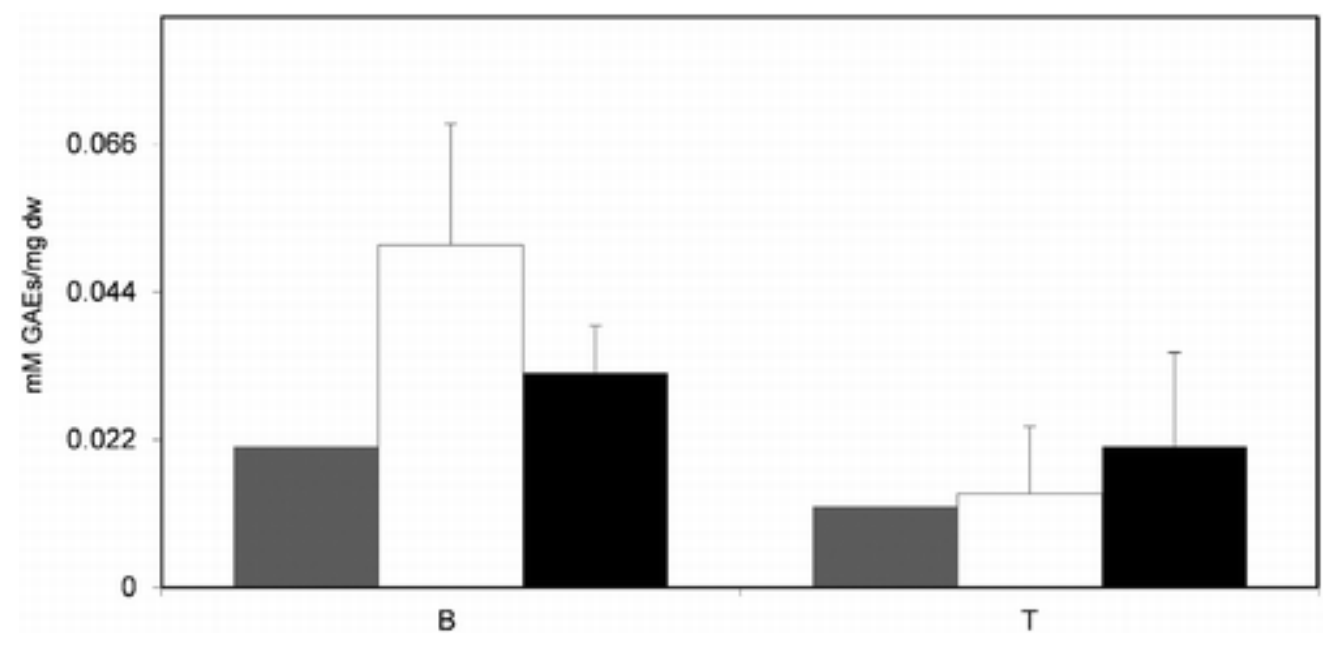

Non-enzymatic antioxidant activity is known to be partly due to the presence of phenolic compounds (Palacios et al. 2011). Our study clearly indicates that G. pannorum can overcome extreme cold conditions by means of a strong antioxidant response mainly through the production of phenolic compounds. G. pannorum is one of the most widespread fungi in Antarctica and its ability to buffer free radical damage with antioxidant compounds is partly responsible for its ability to survive in harsh environments.

\section{Yeasts from the cryosphere}

Yeasts can be defined as fungi whose asexual growth predominantly results from budding or fission, and which do not form their sexual states within or upon a fruiting body (Kurtzman et al. 2011). They include versatile species exhibiting heterogeneous nutritional profiles and a surprising aptitude for survival in a broad range of both natural and man-associated ecosystems (Hagler \& Ahearn 1987; Starmer \& Lachance 2011). Some authors have suggested that yeasts may be better adapted to low temperatures than bacteria (Margesin et al. 2003; Turkiewicz et al. 2003; Shivaji \& Prasad 2009).

The cryosphere represents one of the largest unexplored and extreme biosphere systems, and it includes cold deserts, glacial habitats and permafrost (Margesin \& Miteva 2011).

As studies of Antarctic yeasts have been attracting a considerable amount of interest ever since the 1960s, hundreds of isolates have been characterized and several novel species described (Shivaji \& Prasad 2009). Other glacial habitats are found in Arctic areas and on the glaciers of high-mountain chains, such as the Himalayas, Alps and Andes. Much like the cryosphere found in Antarctica, nonAntarctic cryosphere also harbours psychrophilic yeast life. Indeed, a partially habitat-dependent distribution has been observed in the non-Antarctic cryosphere (Buzzini et al. 2012), and some novel species have recently been described (de García et al. 2010a 2010b; Thomas-Hall et al. 2010; Turchetti et al. 2011; among others).

By comparing the list of yeast species isolated from the cryosphere, it is possible to observe that more than 120 different species have been found worldwide; approximately one third of these species belong to the genus Cryptococcus (Buzzini et al. 2012). As regards the ecology of psychrophilic yeasts that share such habitats, it remains to be seen whether some factors actually 
affect the differential distribution of psychrophilic yeasts in the cryosphere. Moreover, the scientific literature documents the great diversity of isolation protocols used in over 60 years of investigations. As recently pointed out (Shivaji \& Prasad 2009; Buzzini et al. 2012), most previous studies on yeast ecology in the Antarctic and non-Antarctic cryosphere have been conducted using markedly different isolation and incubation protocols. These differences may explain the apparently random distribution observed for most of the psychrophilic yeasts that inhabit cryosphere ecosystems (Vishniac 2006a, 2006b).

A considerable number of structural and functional mechanisms highlighting adaptation strategies adopted by psychrophilic yeasts to resist the severe conditions in the cryosphere have been reported since the 1960s. Moreover, some recent discoveries shed further light on the mechanisms governing both the survival and growth of psychrophilic yeasts. The adaptation strategies adopted by psychrophilic yeasts to overcome cold conditions in the cryosphere have recently been reviewed (Buzzini et al. 2012).

A number of studies have demonstrated that the ability to adjust membrane fluidity by regulating the synthesis of fatty acids, through mechanisms such as increased fatty acid unsaturation, decreased fatty acid average chain length and decreased sterol/phospholipid ratio, is crucial for adaptation to cold temperatures (Margesin \& Miteva 2001). One of the mechanisms that has been studied most is that related to the unsaturation degree (Rossi et al. 2009).

Studies on the synthesis of antifreeze macromolecules have shown that trehalose biosynthesis pathways are found extensively in nature as a form of cell protection against osmotic stress. High cytoplasm concentrations of trehalose have been observed in Mrakia frigida and Leucosporidium fellii as a strategy to reduce the freezing point of intracellular fluid (Deegenaars \& Watson 1997; Deegenaars \& Watson 1998). More recently, Lee et al. (2010) reported the ability of an Arctic Leucosporidium sp. strain to secrete a glycosylated ice-binding protein.

The ability of psychrophilic yeasts to remain metabolically active in sub-zero temperatures was recently reported (Amato et al. 2009). Furthermore, recent comparisons of the dependence of growth kinetic parameters of psychrophilic and mesophilic yeasts within a wide range of temperatures revealed a clear dichotomy: the temperature at which microbial growth was fastest was generally different from the temperature that allowed the production of the highest amount of yeast biomass (Margesin 2009; Rossi et al. 2009).

The synthesis of psychrophilic enzymes is one of the psychrophilic yeast adaptation strategies which has been investigated most. The increased activity of psychro-enzymes at low temperatures is based on their improved structural flexibility in conjunction with a possible modification of the active site (Gerday et al. 1997; Feller \& Gerday 2003). The enhanced plasticity of psychro-enzymes is frequently considered to be responsible for their weak thermal stability. This is due to their adaptation to cold conditions, which has led to structural changes that have increased sensitivity to various denaturing agents, thus pointing to a direct link between activity and stability of psychro-enzymes (Feller \& Gerday 2003).

\section{Macrofungal species from alpine ecosystems}

Glacier forefronts are of particular importance because they represent a newly formed or exposed substrate that constitutes a unique habitat for primary succession and for ruderal organisms (Alfredsen \& Høiland 2001). This habitat provides extreme examples of disturbance in which the primary production and amount of dead plant material are low above all because of slow nutrient turnover (Haselwandter \& Read 1980). As a consequence, newly formed glacier forefronts are characterized by low nitrogen and organic matter levels (Jumpponen et al. 2012).

Fungi play a very important role in the initial colonization of these environments through a range of spore dispersal strategies that render different taxa more or less effective in inoculating these soils and hence in supporting the early establishment of mycorrhizal host plants (Cázares \& Trappe 1994). Some studies have shown that the number of macrofungi in glacier forefronts rises as 
deglaciation increases (Jumpponen et al. 1999), and the success of plant growth may be at least partly attributable to their mycorrhizal associations (Read \& Haselwandter 1981).

Alpine tundra is another very important habitat, characterized by low thermal energy, temperature and nutrient supply, and high proportions of UV light, wind, snow and ice. Fungi have adapted to these life conditions just as other organisms have (Trappe 1988). Indeed, the short growth period favours short life cycles, with the suppression of the conidial or ascomatal state.

Physiological and biochemical adaptations to freezing temperatures, such as a change in the distribution of viable cytoplasm within hyphae in winter, might allow the mycelium to survive freezing events (Addy et al. 1994). Dwarfism, expressed in a reduced number of gills, and the size of the fruit bodies is another very common feature of alpine macrofungi.

Since macrofungi communities have rarely been studied in the alpine habitats of Italy, knowledge of the fungal flora in such environments is based on a limited number of sites (Jamoni 2008; Granito \& Lunghini 2011; Venturella et al. 2011).

A recent contribution to our knowledge of fungal biodiversity in Italian high-mountain habitats has been provided by the PRIN 2008 project "Study and conservation of the fungal biodiversity in cold marginal habitats endangered from global change”, which was designed to analyse the fungal communities in alpine environments characterized by the presence of glaciers found in the Apennines and Alps. These environments include the "Val Viola Bormina-Ghiacciaio Cima dei Piazzi” (IT 2040012) Site of Community Importance belonging to the EU Network "Natura 2000", which was investigated in 2010. The site, which lies at an altitude ranging from 1710 to $3441 \mathrm{~m}$ a.s.l. and located in the Central Alps, in Lombardy, is mostly covered by natural and semi-natural alpine and boreal grasslands (Parolo et al. 2008). Sporomata were collected during the summer and fungal taxa were identified. Fresh material was dried and voucher specimens were deposited in the Herbarium of the Department of Earth and Environmental Sciences, University of Pavia (Italy).

A total of 27 macrofungal species belonging to 17 genera (all members of phylum Basidiomycota) were identified. These include 14 Arctic-alpine species and 13 typical grassland taxa or ubiquitous species that occur in various habitats and frequently also appear in the alpine zone. The species collected contain some taxa that are remarkable on account of their rarity and geographical distribution. Lactarius salicis-herbaceae Kühner, one of the yellow alpine Lactarius species with violet staining milk, was collected from two alpine grassland plots (at 2290 and $2460 \mathrm{~m}$ a.s.l.) with snow bed vegetation including Salix shrubs, on calcareous soil. This is the first record of L. salicis-herbaceae in Lombardy. The fungus has previously been reported in the Italian Alps (Jamoni 2008) in localities with acidic soil. The white to cream lamellae and the relatively darker pileus (yellow to ochre), as well as the preference for acidic habitats, distinguish $L$. salicisherbaceae from the similar L. salicis-reticulatae Kühner, which is characterized by deep yellow lamellae (almost peach coloured) that contrast with the pale (cream yellow, ivory, whitish towards margin) pileus, and grows on basic soil (Alfredsen \& Høiland 2001; Gulden 2005). The finding of L. salicis-herbaceae for the first time on a calcareous bedrock widens both the ecological preferences and the geographic distribution of this species.

Inocybe microfastigiata Kühner was also collected near L. salicis-herbaceae. This small Inocybe species, which usually grows in association with dwarf willows, is found in the highmountain belts of European mountains, having been reported in the Swiss, French and Italian Alps as well as in the Romanian southern Carpathians (Jamoni \& Bon 1995; Ronikier 2008, among others). It represents a typical example of fungal alpine dwarfism as its basidiomes are much smaller (cap 1.5-2 cm in diameter, stipe $2-2.5 \times 0.3 \times 0.4 \mathrm{~cm}$ ) than those of the very similar species I. rimosa (Bull.) P. Kumm. (cap 7-10 cm in diameter, stipe $10 \times 0.3-1.2 \mathrm{~cm}$ ). The taxonomy of the I. rimosa group was somewhat confused for a long time and requires further revision since many species are described on the basis of small macro- and micro-morphological differences (Larsson et al. 2009). The exact ecology and geographical distribution of I. microfastigiata are not known. In this paper, I. microfastigiata is reported as the first record in Lombardy. 
Another ectomycorrhizal basidiomycete observed was Laccaria montana Singer, which normally grows in the alpine zone (Mueller 1992; Kernaghan 2001). Twenty sporocarps of this fungus were collected from one plot at $2460 \mathrm{~m}$ a.s.l. L. montana appears to be morphologically similar to L. pumila Fayod and L. tortilis (Bolton) Cooke, but differs insofar as the latter have twospored basidia (Osmundson et al. 2005). Despite being very similar, the small and striate forms of L. laccata (Scop.) Cooke var. pallidifolia (Peck) Peck differ insofar as L. montana has smaller, globose to subglobose basidiospores (Gulden 2005; Osmundson et al. 2005). L. montana is restricted to Arctic, boreal and montane habitats and seems to prefer relatively disturbed soils present on ridges, open snow-beds, paths or open sandy areas (Alfredsen \& Høiland 2001). This species has been reported in the eastern and western Italian Alps (Bon 1987; Lo Bue et al. 1994; Jamoni 2008), but has not previously been reported in Lombardy.

Another study was conducted in two permanent plots of alpine grassland (about $1000 \mathrm{~m}^{2}$ each) situated along the path leading to Camoscere Lake (Elva, Cuneo, $2294 \mathrm{~m}$ ) in southern Piedmont. The plots, which were visited during the summer months from 2004 to 2011, are dominated by the presence of Helianthemum nummularium (L.) Mill. subsp. grandiflorum (Scop.) Schinz \& Thell plants. Although the vegetation is scarce, there is an abundance of ectomycorrhizal (ECM) fungi, which is indicative of these fungi's association with Helianthemum spp. Nine species were recorded, including a new taxon: Amanita helianthemicola Zotti, Vizzini \& Traverso (Vizzini et al. submitted). The new species belongs to the A. lividopallescens complex in the section Vaginatae (Fr.) Quél. (Contu 2001); it is very closely related to A. lividopallescens sensu Boudier (Boudier 1905), and is characterized by clampless basidia and globose inamyloid basidiospores.

The other ECM species observed were A. pantherina (DC.) Krombh., A. vaginata (Bull.) Lam., Boletus luridus Schaeff., Cortinarius anomalus (Fr.) Fr. and Russula pascua (F.H. Møller \& Jul. Schäff.) Kühner. It is noteworthy that a significant number of sporomata were observed during surveys, i.e. from 6 to 45 for each species. Besides the ECMs, three saprotrophic species were also collected: Lepista irina (Fr.) H.E. Bigelow var. montana Bon, Agaricus campestris L. and Bovista plumbea Pers.

Our data suggest that Helianthemum nummularium subsp. grandiflorum creates a suitable habitat for the growth of a wide range of ECM species, as it has previously been highlighted for $H$. nummularium subsp. nummularium by Barden (2007) in English grasslands. Helianthemum is known to form ectomycorrhizal associations, particularly with hypogeous ascomycetes in Mediterranenan areas (Turgeman et al. 2011), whereas species strictly associated with Helianthemum have rarely been reported in alpine grasslands (Barden 2007).

\section{Acknowledgements}

The authors thank the Italian National Program for Research in Antarctica (PNRA), and the National Scientific Fund of the Ministry of Education and Science, Bulgaria (grant DO02-172/08); PRIN 2008: 2008AR8MX9 002 and Estonian Science Foundation and the European Social Fund (Mobilitas Postdoctoral Research Grant MJD135). The authors would like to thank Dr George Zervakis for helping to revise the language in the manuscript.

\section{References}

- 1. Abyzov, SS. 1993. "Microorganisms in the Antarctic ice”. In Antarctic microbiology, Edited by: Friedmann, EI. New York: Wiley-Liss.

- 2. Addy, HD, Schaffer, GF, Miller, MH and Peterson, RL. 1994. Survival of the external mycelium of VAM fungus in frozen soil over winter. Mycorrhiza, 5: 1-5.

- 3. Alfredsen, G and Høiland, K. 2001. Succession of terrestrial macrofungi along a deglaciation gradient at Glacier Blåisen, South Norway. Nord J Bot, 21(1): 19-37. 
- 4. Amato, P, Doyle, S and Christner, BC. 2009. Macromolecular synthesis by yeasts under frozen conditions. Environ Microbiol, 11: 589-596.

- 5. Angelova, MB, Pashova, SB, Spasova, BK, Vassilev, SV and Slokoska, LS. 2005.

Oxidative stress response of filamentous fungi induced by hydrogen peroxide and paraquat. Mycol Res, 109(2): 150-158.

- 6. Barden, N. 2007. Helianthemum grasslands of the Peak District and their possible mycorrhizal associates. Field Mycol, 8(4): 119-126.

- 7. Benn, DI and Evans, DJA. 1998. Glaciers and glaciation, London: Arnold.

- 8. Bon, M. 1987. Quelques recoltes mycologyques de la zone alpine au 7ème convegno di micologia-Fiera di Primiero (Italie). Mic Ital, 17(3): 267-270.

- 9. Boudier, É. 1905. Icones Mycologicae 1-5 [Série 1], Paris: Paul Klincksieck Press. pls. 1100

- 10. Buzzini, P, Branda, E, Goretti, M and Turchetti, B. 2012. Psychrophilic yeasts from worldwide glacial habitats: Diversity, adaptation strategies and biotechnological potential. FEMS Microbiol Ecol, DOI: 10.1111/j.1574-6941.2012.01348.x

- 11. Catranis, CM and Starmer, WT. 1991. Microorganisms entrapped in glacial ice. Antarct J, 26: 234-236.

- 12. Cázares, E and Trappe, JM. 1994. Spore dispersal of ectomycorrhizal fungi on a glacier forefront by mammal mycophagy. Mycologia, 86(4): 507-510.

- 13. Chattopadhyay, MK. 2002. Low temperature and oxidative stress. Curr Sci, 83(2): 109

- 14. Chattopadhyay, MK, Raghu, G, Sharma, YVRK, Biju, AR, Rajasekharan, MV and Shivaji, S. 2011. Increase in oxidative stress at low Temperature in an Antarctic Bacterium. Curr Microbiol, 62(2): 544-546.

- 15. Cheung, LM, Cheung, PCK and Ooi, VEC. 2003. Antioxidant activity and total phenolics of edible mushroom extract. Food Chem, 81(2): 249-255.

- 16. Contu, M. 2001. A revised key to Amanita section Vaginatae (Fr.) Quél. in Europe. Field Mycol, 4(4): 128-136.

- 17. D'Amico, S, Collins, T, Marx, J-C, Feller, G and Gerday, C. 2006. Psychrophilic microorganisms: Challenges for life. EMBO Rep, 7(4): 385-389.

- 18. de García, V, Brizzio, S, Libkind, D, Rosa, CA and van Broock, M. 2010a. Wickerhamomyces patagonicus sp. nov., an ascomycetous yeast species from Patagonia, Argentina. Int J Syst Evol Microbiol, 60: 1693-1696.

- 19. de García, V, Brizzio, S, Russo, G, Rosa, CA, Boekhout, TTheelen, B. 2010b. Cryptococcus spencermartinsiae sp. nov., a basidiomycetous yeast isolated from glacial waters and apple fruits. Int J Syst Evol Microbiol, 60: 707-711.

- 20. Deegenaars, ML and Watson, K. 1997. Stress proteins and stress tolerance in an Antarctic, psychrophilic yeast, Candida psychrophila. FEMS Microbiol Lett, 151: 191-196.

- 21. Deegenaars, ML and Watson, K. 1998. Heat-shock response in psychrophilic and psychrotrophic yeast from Antarctica. Extremophiles, 2: 41-49.

- 22. Dewey, A, Baughan, C, Dean, TP, Higgins, B and Johnson, I. 2007. Eicosapentaenoic acid (EPA, an omega-3 fatty acid from fish oils) for the treatment of cancer cachexia. Cochrane Database Syst Rev, DOI: 10.1002/14651858.CD004597.pub2

- 23. Eddy, BP. 1960. The use and meaning of the term 'psychrophilic'. J Appl Bacteriol, 23(2): 189-190.

- 24. Feller, G and Gerday, C. 2003. Psychrophilic enzymes: Hot topics in cold adaptation. Nat Rev Microbiol, 1: 200-208.

- 25. Finotti, E, Moretto, D, Marsella, R and Mercantini, R. 1993. Temperature effects and fatty acid patterns in Geomyces species isolated from Antarctic soil. Polar Biol, 13: 127130 .

- 26. Fridovich, I. 1998. Oxygen toxicity: A radical explanation. J Exp Biol, 201: 1203-1209. 
- 27. García-Arribas, O, Mateo, R, Tomczak, MM, Davies, PL and Mateo, MG. 2007. Thermodinamic stability of a cold-adapted protein, type III antifreeze protein, and energetic contribution of salt bridge. Protein Sci, 16: 227-238.

- 28. Gatti-Lafranconi, P, Natalello, A, Rehm, S, Doglia, SM, Pleiss, J and Lotti, M. 2010. Evolution of stability in a cold-active enzyme elicits specificity relaxation and highlights substrate-related effects on temperature adaptation. J Mol Biol, 395(1): 155-166.

- 29. Gerday, C. 2002. "Extremophiles: Basic concepts”. In Knowledge for sustainable development. An insight into the encyclopedia of life support systems, Edited by: Gerday, C and Glansdorff, N. Vol. 1, 573-598. Oxford: UNESCO Publishing/EOLSS Publishers. Online publication:

- 30. Gerday, C, Aittaleb, M, Arpigny, JL, Baise, E, Chessa, JPGarsoux, G. 1997. Psychrophilic enzymes: A thermodynamic challenge. Biochim Biophys Acta, 1342: 119131.

- 31. Gocheva, YG, Tosi, S and Krumova, ET. 2009. Temperature downshift induces antioxidant response in fungi isolated from Antarctica. Extremophiles, 13: 273-281.

- 32. Granito, VM and Lunghini, D. 2011. Biodiversity of macrofungi in the beech forests and calcareous grasslands of the Simbruini Mountains Regional Park (Central Apennines, Italy). Plant Biosyst, 145(2): 381-396.

- 33. Gulden G. 2005. A preliminary guide to the macromycetes in the Finse area, Hardangervidda, Norway, Draft presented at ISAM VII, Oslo. P. 81

- 34. Hagler, AN and Ahearn, DG. 1987. "Ecology of aquatic yeasts”. In The yeasts, Edited by: Rose, AH and Harrison, JS. Vol. 1, 181-205. London: Academic Press.

- 35. Haselwandter, K and Read, DJ. 1980. Fungal associations of roots of dominant and subdominant plants in high-alpine vegetation systems with special reference to mycorrhizal. Oecologia, 45: 57-62.

- 36. Horn, G, Hofweber, R, Kremer, W and Kalbitzer, HR. 2007. Structure and function of bacterial cold shock proteins. Cell Mol Life Sci, 64: 1457-1470.

- 37. Jamoni, PG. 2008. Funghi alpini delle zone alpine superiori e inferiori, 1-544. Trento, Italia: AMB Fondazione, Centro Studi Micologici.

- 38. Jamoni, PG and Bon, M. 1995. Note di micologia alpina reperti rari e nuovi della zona alpina del massiccio del Monte Rosa (4e parte). Riv Micol Suppl, 2: 61-74.

- 39. Jang, HD, Lin, YY and Yang, SS. 2005. Effect of culture media and conditions on polyunsaturated fatty acids production by Mortierella alpina. Biores Technol, 96: 16331644.

- 40. Jumpponen, A, Brown, SP, Trappe, JM, Cázares, E and Strömmer, R. 2012. Twenty years of research on fungal-plant interactions on Lyman Glacier forefront - lessons learned and questions yet unanswered. Fungal Ecology, 5: 430-442.

- 41. Jumpponen, A, Trappe, JM and Cázares, E. 1999. Ectomycorrhizal fungi in Lyman Lake Basin: A comparison between primary and secondary successional sites. Mycologia, 91(4): 575-582.

- 42. Kernaghan, G. 2001. Ectomycorrhizal fungi at tree line in the Canadian Rockies II. Identification of ectomycorrhizae by anatomy and PCR. Mycorrhiza, 10: 217-229.

- 43. Kostadinova, N, Krumova, E, Pashova, S, Miteva-Staleva, J, Abrashev, RTosi, S. Coldstress adaptation in Antarctic fungi. New trends in microbiology, 65th anniversary of the Stephan Angeloff Institute of Microbiology, 2012, 15 March, Sofia, Bulgarian Academy of Sciences, pp. 159-175.

- 44. Krumova, E, Abrashev, R, Kostadinova, N, Dishlijska, V, Miteva-Staleva, JPashova, S. Novel cold-Active antioxidant enzymes from Antarctic fungi. New trends in microbiology, 65th anniversary of the Stephan Angeloff Institute of Microbiology, 2012, 15 March, Sofia, Bulgarian Academy of Sciences, pp. 291-305 
- 45. Kurtzman, CP, Fell, JW and Boekhout, T. 2011. "Definition, classification and nomenclature of the yeasts". In The yeasts, a taxonomic study, 5th ed., Edited by: Kurtzman, CP, Fell, JW and Boekhout, T. 3-5. Amsterdam: Elsevier.

- 46. Kwak, KJ, Park, SJ, Han, JH, Kim, MK, Han, OSHan, YS. 2011. Structural determinants crucial to the RNA chaperone activity of glycine-rich RNA-binding proteins 4 and 7 in Arabidopsis thaliana during the cold adaptation process. $J$ Exp Bot, 62(11): 40034011.

- 47. Larsson, E, Ryberg, M, Moreau, P-A, Mathiesen, D and Jacobsson, S. 2009. Taxonomy and evolutionary relationships within species of section Rimosae (Inocybe) based on ITS, LSU and mtSSU sequence data. Persoonia, 23: 86-98.

- 48. Lee, JK, Park, KS, Park, S, Park, H, Song, YHKang, SH. 2010. An extracellular icebinding glycoprotein from an Arctic psychrophilic yeast. Cryobiology, 60: 222-228.

- 49. Lo Bue, G, Montacchini, F and Ceruti, A. 1994. Macromycetes of the alpine belt: mycocoenological investigations in the western Italian Alps by multivariate methods. Coenoses, 9(3): 103-153.

- 50. Margesin, R. 2009. Effect of temperature on growth parameters of psychrophilic bacteria and yeasts. Extremophiles, 13: 257-262.

- 51. Margesin, R, Gander, S, Zacke, G, Gounot, AM and Schinner, F. 2003. Hydrocarbon degradation and enzyme activities of cold-adapted bacteria and yeasts. Extremophiles, 7: 451-458.

- 52. Margesin, R and Miteva, V. 2011. Diversity and ecology of psychrophilic microorganisms. Res Microbiol, 162: 346-361.

- 53. Molyneux, P. 2004. The use of the stable free radical diphenylpicrylhydrazyl (DPPH) for estimating antioxidant activity. Songklanakarin J Sci Technol, 50: 211-219.

- 54. Morita, RY. 1975. Psychrophilic bacteria. Bacteriol Rev, 39: 146-167.

- 55. Moss, CW, Dees, SB and Guerrat, GO. 1980. Gas-liquid chromatography of bacterial fatty acids with a fused silica capillary column. J Clin Microbiol, 12: 127-130. 56. Mueller, GM. 1992. Systematics of Laccaria (Agaricales) in the continental United States and Canada, with discussions on extralimital taxa and descriptions of extant types, 158Chicago, IL: Field Museum of Natural History Press. Fieldiana 1435 New Series no. 30.

- 57. Newsham, KK. 2012. Fungi in extreme environments. Fungal Ecol, 5: 379-380.

- 58. Onofri, S, Anastasi, A, Del Frate, G, Di Piazza, S, Garnero, NGuglielminetti, M. 2011. Biodiverisity of rock, beach and water fungi in Italy. Plant Biosyst, 145(4): 978-987.

- 59. Onofri, S, Zucconi, L and Tosi, S. 2007. Continental Antarctic fungi, 247Eching: IHWVerlag.

- 60. Osmundson, TW, Cripps, CL and Mueller, GM. 2005. Morphological and molecular systematics of Rocky Mountain alpine Laccaria. Mycologia, 97(5): 949-972.

- 61. Palacios, I, Lozano, M, Moro, C, D'Arrigo, M, Rostagno, MAMartinez, JA. 2011. Antioxidant properties of phenolic compounds occurring in edible mushrooms. Food Chem, 128: 674-678.

- 62. Parolo, G, Rossi, G and Ferrarini, A. 2008. Toward improved species niche modelling: Arnica montana in the Alps as a case study. J Appl Ecol, 45: 1410-1418.

- 63. Persiani, AM, Tosi, S, Del Frate, G, Granito, VM, Guglielminetti, MLunghini, D. 2011. High spots for diversity of soil and litter micro fungi in Italy. Plant Biosyst, 145(4): 969977.

- 64. Pitt, JI and Hocking, AD. 1985. Fungi and Food Spoilage, 413Sydney: Academic Press.

- 65. Read, DJ and Haselwandter, K. 1981. Observations on the mycorrhizal status of some alpine plant communities. New Phytol., 88: 341-352.

- 66. Robinson, CH. 2001. Cold adaptation in Arctic and Antarctic fungi. New Phytol., 151: 341-353. 
- 67. Ronikier, A. 2008. Contribution to the biogeography of arctic-alpine fungi: First records in the Southern Carpathians (Romania). Sommerfeltia, 31: 191-211.

- 68. Rossi, M, Buzzini, M, Cordisco, L, Amaretti, A, Sala, MRaimondi, S. 2009. Growth, lipid accumulation, and fatty acids composition in obligate psychrophilic, facultative psychrophilic and mesophilic yeasts. FEMS Microbiol Ecol, 69: 363-372.

- 69. Ruisi, S, Barreca, D, Selbmann, L, Zucconi, L and Onofri, S. 2007. Fungi in Antarctica. Rev Environ Sci Biotechnol, 6: 127-141.

- 70. Russell, NJ. 1990. Cold adaptation of microorganisms. Philos Trans R Soc Lond Ser B, 326: 595-611.

- 71. Russell, NJ. 2008. "Membrane components and cold sensing. Fundamentals of ColdAdapted Enzymes”. In Psychrophiles: From biodiversity to biotechnology, Edited by: Margesin, R, Schinner, F, Marx, JC and Gerday, C. 177-190. Berlin: Springer-Verlag.

- 72. Russell, NJ. 2009. "Psychrophily and resistance to low temperature". In Extremophiles, Edited by: Glandsdorff, N. Vol II, 1-32. Isle of Man: EOLSS Publishers Co. Ltd.

- 73. Selbmann L, Egidi E, Isola D, Onofri S, Zucconi L, De Hoog GS, et al. 2013. Biodiversity evolution and adaptation of fungi in extreme environments. Plant Biosyst.147: 242-251

- 74. Shivaji, S and Prasad, GS. 2009. "Antarctic yeasts: Biodiversity and potential applications”. In Yeast biotechnology: Diversity and applications, Edited by: Satyanarayana, T and Kunze, G. 3-16. Berlin: Springer-Verlag.

- 75. Singleton, VL, Orthofer, R and Lamuela-Raventos, RM. 1999. Analysis of total phenols and other oxidation substrates and antioxidants by means of Folin-Ciocalteu Reagent. Method Enzymol, 299: 152-178.

- 76. Starmer, WT and Lachance, MA. 2011. "Yeast ecology". In The yeasts, a taxonomic study, 5th ed., Edited by: Kurtzman, CP, Fell, JW and Boekhout, T. 65-83. Amsterdam: Elsevier.

- 77. Thomas-Hall, SR, Turchetti, B, Buzzini, P, Branda, E, Boekhout, TTheelen, B. 2010. Cold adapted yeasts from Antarctica and the Italian Alps. Description of three novel species: Mrakia robertii sp. nov., Mrakia blollopis sp. nov. and Mrakiella niccombsii sp. nov. Extremophiles, 14: 47-59.

- 78. Tosi, S, Kostadinova, N, Krumova, E, Pashova, S, Dishliiska, VSpassova, B. 2010. Antioxidant enzyme activity of filamentous fungi isolated from Livingston Island, Maritime Antarctica. Polar Biol, 33(9): 1227-1237.

- 79. Trappe, MJ. 1988. Lessons from alpine fungi. Mycologia, 80(1): 1-10.

- 80. Turchetti, B, Thomas-Hall, SR, Connell, LB, Branda, E, Buzzini, PTheelen, B. 2011. Psychrophilic yeasts from Antarctica and European glaciers: description of Glaciozyma gen. nov. Glaciozyma martinii sp. nov. and Glaciozyma watsonii sp. nov. Extremophiles, 15: 573-586.

- 81. Turgeman, T, Ben Asher, J, Roth-Bejerano, N, Kagan-Zur, V, Kapulnik, Y and Sitrit, Y. 2011. Mycorrhizal association between the desert truffle Terfezia boudieri and Helianthemum sessiliflorum alters plant physiology and fitness to arid conditions. Mycorrhiza, 21: 623-630.

- 82. Turk, M, Plemenitas, A and Gunde-Cimerman, N. 2011. Extremophilic yeasts: Plasmamembrane fluidity as determinant of stress tolerance. Fungal Biol, 115: 950-958.

- 83. Turkiewicz, M, Pazgier, M, Kalinowska, H and Bielecki, S. 2003. A cold-adapted extracellular serine proteinase of the yeast Leucosporidium antarcticum. Extremophiles, 7: 435-442.

- 84. Venturella, G, Altobelli, E, Bernicchia, A, Di Piazza, S, Donnini, DGargano, ML. 2011. Fungal biodiversity and in situ conservation in Italy. Plant Biosyst, 145(4): 950-957. 
- 85. Vishniac, HS. 2006a. "Yeast biodiversity in the Antarctic". In The yeast handbook. Biodiversity and ecophysiology of yeasts, Edited by: Rosa, CA and Gabor, P. 419-440. Berlin: Springer-Verlag.

- 86. Vishniac, HS. 2006b. A multivariate analysis of soil yeasts isolated from a latitudinal gradient. Microb Ecol, 52: 90-103.

- 87. Vizzini A, Zotti M, Traverso M, Contu M, Ercole E. (Submitted). Amanita helianthemicola: a new species of Amanita section Vaginatae In: Wrolstad, editor. Mycol Prog.

- 88. Waterhouse, AL. 2001. Determination of total phenolics. Current protocols in food analytical chemistry unit, : I.1.1.1-I.1.1.8. New York: John Wiley \& Sons Inc.

- 89. Weete, JD and Gandhi, SR. 1999. Sterols and fatty acids of the Mortierellaceae: Taxonomic implications. Mycologia, 91(4): 642-649.

- 90. Weinstain, RN, Montiel, PO and Johnstone, K. 2000. Influence of groth temperature on lipid and soluble carbohydrate synthesis by fungi isolated from fellfield soil in the maritime Antarctic. Mycologia, 92(2): 222-229. 